\title{
Birokrat Melawan:
}

\section{Mempertahankan Integritas \\ di Tengah Budaya}

Paternalistik (Studi Kasus di

\section{Pemerintah Kota Tegal)}

\section{MUTIA RIZAL DAN ILHAM NURHIDAYAT \\ Pergerakan Birokrat Menulis (birokratmenulis.org)}

mutiarizal@gmail.com

ilhamnurhidayat@gmail.com

p-ISSN: 2477-118X

e-ISSN: 2615-7977

\section{A B S T RAK}

Tidak dapat dimungkiri, keberanian seseorang untuk mempraktikkan integritas secara nyata di tengah budaya paternalistik yang telah mengakar kuat di birokrasi, masih cukup sulit. Budaya paternalistik semakin tumbuh subur di tengah masyarakat Indonesia yang cenderung memiliki sikap kolektivis dibanding individualis. Budaya ini juga menciptakan kesenjangan kekuasaan yang cukup lebar antara patron dengan client. Client tidak dapat leluasa mengingatkan atau melawan patron yang diketahui melakukan tindakan menyim- 
pang. Perilaku birokrat (client) yang ingin mempraktikkan integritasnya, seringkali tidak didukung secara kultural oleh lingkungan. Operasi Tangkap Tangan (OTT) yang dilakukan Komsi Pemberantasan Korupsi (KPK) terhadap Wali Kota Tegal, SMS yang direspons dengan beragam ekspresi dan dirayakan secara terbuka, merupakan kejadian yang menarik untuk dicermati. Kondisi itu menggambarkan adanya titik klimaks sebuah perjuangan melawan berbagai penyimpangan yang dilakukan wali kota. Sebuah perjuangan yang tidak mudah di tengah budaya paternalistik. Gerakan perlawanan untuk mempertahankan kelangsungan hidup birokrasi dan nilai budaya setempat, menjadi bukti bahwa birokrat juga mampu melawan. Meskipun tidak disadari oleh para birokrat, perlawanan ini pada dasarnya juga sekaligus merupakan perlawanan terhadap budaya paternalistik. Perlawanan dilakukan dengan cara mengungkap berbagai penyimpangan informasi yang dilakukan wali kota. Melalui pendekatan kajian budaya, penulis mempelajari dari dekat, proses perlawanan dilakukan para birokrat di Kota Tegal. Data diperoleh melalui wawancara mendalam kepada berbagai tokoh pergerakan dan para birokrat di Pemkot Tegal. Tindakan pengungkapan tersebut berbeda dengan pengungkapan pada umumnya yang dilakukan secara sporadis oleh seorang individu. Pengungkapan tersebut dilakukan secara kolektif dalam sebuah pergerakan yang terorganisasi melalui lembaga yang legitimate. Perlawanan kolektif menjadi sebuah strategi efektif, mengingat kentalnya budaya paternalistik juga menginginkan kepatuhan kolektif.

Kata kunci: budaya, integritas, paternalistik, perlawanan, whistleblowing.

\section{A B S TRACT}

Undeniably, the courage to manifest integrity for the individual was actually still quite difficult to implement in the midst of paternalistic culture that had been entrenched in the bureaucracy.Paternalistic culture maturated in Indonesian society who tended to have 
collectivist rather than individualistic attitudes. This culture also creates a fairly wide power distance between patron and client. A client could not be free to warn or against patrons who perform wrongdoings. Bureaucratic resistance (clients) who had been willing to act to practice their integrity, but were not culturally supported. KPK Arrest Operation (OTT) to Tegal Mayor-SMS responded by various expressions and openly celebrated was an interesting phenomenon to be observed.It illustrated the climactic point of a struggle against various irregularities committed by the mayor. A struggle that was not easy in the midst of paternalistic culture. The resistance movement to maintain the bureaucracy's survival and local cultural values, proved that bureaucrats were also able to resist. Although not realized by the bureaucrats, basically resistance will also be the resistance against the paternalistic culture. Resistance was conducted by revealing various information deviations made by the mayor. Through a cultural studies approach, author studied closely how the process of resistance was done by the bureaucrats in the bureaucratic environment. The data were obtained through in-depth interviews with various movement figures and bureaucrats in Tegal City. The whistleblowing action undertaken by the bureaucrats of Tegal City differed from the general whistleblowing actions performed sporadically by an individual. The whistleblowing was conducted collectively in an organized movement through legitimate institution. This collective whistleblowing became an effective strategy, given the strong paternalistic culture that also wanted collective obedience.

Keywords: culture, integrity, paternalistic, resistance, whistleblowing. 


\section{A. PENDAHULUAN}

Peristiwa setelah terjadinya Operasi Tangkap Tangan (OTT) yang dilakukan Komisi Pemberantasan Korupsi (KPK) di Kota Tegal pada akhir Agustus 2017, menjadi sebuah peristiwa menarik untuk dicermati. Berdasarkan informasi valid, KPK berhasil menangkap Wali Kota Tegal, Siti Mashita Soeparno (SMS), yang sedang menerima suap dari rekanan. Setelah peristiwa OTT, seperti yang diberitakan beberapa media (Nugroho, 2017), beberapa birokrat melakukan sujud syukur dan bereaksi secara terbuka sebagai luapan rasa suka cita. Beberapa birokrat yang merayakan peristiwa tersebut adalah mereka yang berani melawan berbagai tindakan wali kota yang dinilai tidak sesuai dengan ketentuan dalam birokrasi maupun nilai-nilai budaya masyarakat Kota Tegal.

Perlawanan yang dilakukan oleh para birokrat Pemerintah Kota (Pemkot) Tegal terhadap pimpinannya, merupakan kejadian unik dan belum pernah terjadi sebelumnya di instansi pemerintah, baik pusat maupun daerah di Indonesia. Beberapa peristiwa perlawanan terhadap kepala daerah melalui berbagai aktivitas demonstrasi dan perlawanan lainnya memang juga terjadi di beberapa tempat, tetapi perlawanan tersebut bukan atas inisiatif para birokrat dari dalam tubuh birokrasi, melainkan atas inisiatif aktivis dari elemen masyarakat nonbirokrasi.

Dalam birokrasi, khususnya di Indonesia, birokrat tidak bersedia melaksanakan kebijakan pimpinannya adalah hal yang tabu karena dianggap sebagai pembangkangan, terlebih jika dilakukan secara terbuka. Alih-alih perlawanannya berhasil, seringkali perlawanan justru berujung pada penurunan jabatan, hambatan karir ataupun pemecatan karena dianggap tidak loyal terhadap pimpinan. Kondisi tersebut dikarenakan budaya dominan yang meliputi birokrasi adalah budaya paternalistik. Menurut Dwiyanto (2012), budaya tersebut berasal dari zaman feodal (kerajaan) dan semakin subur di era kolonial (penjajahan). Sampai saat ini, budaya tersebut masih lekat dan sulit dihilangkan dari tubuh birokrasi. Budaya pater- 
nalistik dalam birokrasi, khususnya pemerintahan, menunjuk pada hubungan antara pimpinan sebagai patron, dengan bawahan sebagai client. Relasi keduanya cenderung menggambarkan hubungan superior-inferior (powerfull-powerless).

Budaya paternalistik, menurut Jackson (2016) tumbuh subur pada lingkungan, yang oleh Hofstede (1980) disebut sebagai kolektivisme (collectivism). Adapun Indonesia, menurut riset yang dilakukan oleh Hofstede Insight (2017), diidentifikasikan sebagai negara yang memiliki budaya kolektivis daripada individualistik. Dalam riset tersebut, Indonesia memiliki tingkat individualistik yang rendah (14 dari skala 100), dengan kata lain, kolektivis menjadi cara masyarakat Indonesia bersosialisasi. Pada sisi lain, di riset yang sama, Indonesia memiliki jarak kekuasaan (power distance) yang cukup tinggi (78 dari skala 100). Temuan tersebut menggambarkan bahwa jarak kekuasaan antara pihak powerfull dan powerless masih cukup lebar. Oleh sebab itu, Indonesia yang kolektivis menjadi lahan subur budaya paternalistik yang hierarkis.

Dalam kondisi demikian, tidak mudah bagi birokrat untuk dapat mempertahankan integritas pribadinya tatkala berbenturan dengan kepentingan atasan yang melakukan tindakan tidak benar (wrongdoing). Perilaku birokrat untuk mencoba mempertahankan integritasnya di hadapan pimpinan, dapat berujung pada anggapan pembangkangan ataupun perlawanan. Salah satu jalan yang ditempuh adalah mengungkapkan tindakan pimpinan kepada pihak yang independen. Namun demikian, seorang birokrat memerlukan keberanian yang cukup untuk memberikan informasi kepada pihak independen, sekalipun pihak independen tersebut adalah institusi terpercaya. Hanya saja, mereka sering dihampiri ketakutan di saat lingkungan sekitar tidak mendukungnya.

Pergerakan perlawanan para birokrat di Pemkot Tegal yang dilakukan secara kolektif menarik untuk dikaji agar dapat menjadi sebuah pembelajaran (transformative learning) bagi birokrat pada instansi atau daerah lain dalam upaya mempertahankan integritasnya. Upaya tersebut juga dapat menjadi sebuah pembuktian bahwa 
posisi birokrat bukan lagi sebuah kelas yang inferior, tetapi mampu menjadi sebuah kekuatan yang diperhitungkan oleh pihak yang selama ini merasa superior, yaitu para politisi dan pejabat tinggi.

\section{Rumusan Masalah}

Penguatan integritas di birokrasi menemui kesulitan tatkala berbenturan dengan dominasi budaya paternalistik yang sudah mapan di birokrasi. Budaya ini memiliki kekuatan utama, yaitu mampu memosisikan birokrat sebagai pihak inferior yang pasif dalam berpikir dan berperilaku. Keinginan bahkan keberanian untuk berintegritas, termasuk dalam mengungkapkan tindakan koruptif yang dilakukan atasan atau kelas superior. Hal ini selalu dibayangi dengan anggapan ketidakpatuhan maupun ketidaksetiaan, yang dapat mengakibatkan penyingkiran tubuh seorang pengungkap dari lingkungan kulturalnya.

Di tengah budaya paternalistik yang menyelimuti birokrasi, kemungkinan terdapat sebuah tindakan perlawanan yang bertujuan mempertahankan nilai-nilai budaya yang diyakini telah menjadi nilai keutamaan di dalam suatu komunitas masyarakat. Perlawanan itu telah dicontohkan oleh birokrat Kota Tegal yang tentu saja menarik untuk diteliti dengan menggunakan tinjauan kultural. Hal mana memberikan pemahaman bagaimana perilaku sekumpulan individu pada sebuah komunitas merespons lingkungannya dan bertindak sesuai dengan nilai-nilai yang dianutnya.

Berdasar latar belakang dan rumusan masalah di atas, penelitian dilakukan untuk menjawab beberapa pertanyaan berikut:

a. Mengapa birokrat Kota Tegal berani melawan kekuatan dominasi budaya paternalistik untuk mempertahankan integritasnya?

b. Bagaimana mekanisme perlawanan yang dilakukan oleh para birokrat Kota Tegal? 


\section{Pendekatan Penelitian}

Penelitian bertemakan penguatan integritas di lingkungan birokrasi ini dilihat dari perspektif kajian budaya (cultural studies). Dengan perspektif ini, pokok persoalan dikaji dari sudut praktik kebudayaan. Dengan demikian, fenomena yang ditemui dalam penelitian ini merupakan fenomena kompleks yang tidak linier dan tidak netral (Storey, 2008). Diperlukan penelusuran makna atas berbagai peristiwa yang sifatnya subjektif, dengan cara tidak menjaga jarak dengan objek penelitian.

Penelitian dilakukan secara kualitatif, oleh karena itu penulis memperlakukan data sebagai sesuatu yang bermakna intrinsik (Neuman, 2013). Data yang ada dalam penelitian ini terdiri dari dokumentasi ragam peristiwa, rekaman ucapan, kata dan gestur dari objek kajian, tingkah laku yang spesifik, dokumen-dokumen tertulis, serta berbagai imaji visual yang ada dalam sebuah fenomena sosial.

\section{Tinjauan Teori}

\section{1.Budaya dan Perlawanannya}

Budaya (kultur) dalam kajian budaya (culture studies), lebih didefinisikan secara politis, bukan estetis (Barker, 2009). Objek kajiannya bukanlah budaya dalam pengertian sempit, yaitu objek adiluhung, juga bukan dalam pengertian sebuah perkembangan estetik, intelektual, dan spiritual. Budaya dipahami sebagai teks dan praktik hidup sehari-hari, sebagai ranah konflik dan pergumulan. Budaya dapat digambarkan sebagai sebuah arena konsensus dan resistensi, merupakan tempat dimana hegemoni muncul dan berlangsung (Storey, 2008).

Dengan demikian, anggota komunitas secara kreatif mampu merespons relasi sosial menjadi eksistensi mereka melalui logika tindakan kultural. Logika tindakan kultural dirumuskan oleh Barker (2009) dalam konsep homologi, sebagai sebuah konsep yang mengaitkan budaya yang hidup di suatu tempat sebagai serangkaian relasi konstitutif dengan objek, artefak, institusi dan praktik sistematis kebudayaan yang mengitarinya. 
Homologi terkait sejauh mana item-item dalam struktur, yang biasanya terkait dengan simbol, mencerminkan gaya, tipe, sikap, dan perasaan kelompok sosial tertentu. Permainan item-item ini dalam sebuah kelompok akan menghasilkan gaya, makna, kandungan, dan bentuk-bentuk kesadaran praktik yang spesifik. Oleh karenanya, studi budaya seringkali memasukan studi tentang simbolisme (bahasa, pakaian, ataupun perilaku) sekaligus bagaimana simbol tersebut diinterpretasikan.

Menurut McGuigan (1992), di komunitas budaya, ada sejumlah landasan untuk mengkritik suatu tatanan yang sudah mengakar dalam budaya, atau memberikan sebuah visi alternatif baginya. Kegiatan mengkritik sebuah tatanan budaya yang mampu memberikan visi alternatif dapat dikategorikan sebagai sebuah perlawanan (counter) terhadap budaya.

Konsepsi menarik tentang perlawanan budaya datang dari Hebdige (2003), yang mengatakan bahwa perlawanan bukan sebagai kualitas atau tindakan tetap namun sebagai sesuatu yang relasional dan konjungtural. Artinya, seperti diungkapkan oleh Hall (1996), perlawanan tidak dipahami sebagai sesuatu yang tunggal dan universal untuk segala waktu, namun sebagai sesuatu yang membentuk makna khas untuk waktu, tempat, dan hubungan sosial tertentu. Dengan demikian untuk memahami sebuah perlawanan, perlu kiranya kita menjawab beberapa pertanyaan seputar apa atau siapa yang dilawan, di bawah kondisi/situasi macam apakah perlawanan termanifestasi, dan dimana perlawanan terjadi.

Bagi Bennet (dalam Storey, 2008), pemahaman perlawanan tersebut adalah pemahaman yang produktif karena secara jelas berbicara tentang persoalan apa, siapa, dimana, dan kapan perlawanan itu terjadi. Ini berbeda dengan rumusan perlawanan mainstream yang tidak spesifik, yang menganggap setiap respons terhadap kekuasaan atau budaya dominan sebagai perlawanan. Bennet (1998) mendeskripsikan bahwa perlawanan pada dasarnya adalah sebuah pertahanan (defensive) terhadap kekuatan kultural yang diadaptasi oleh kekuatan sosial subordinat. Adapun secara normatif, menurut 
Barker (2009), perlawanan bukanlah soal kebenaran atau kepalsuan, melainkan soal manfaat atau nilai. Perlawanan adalah suatu konsep normatif yang keberhasilannya diukur secara strategis berdasarkan kriteria normatif. Perlawanan semestinya dikerangkakan dalam upaya mewujudkan nilai-nilai tertentu.

\section{2.Budaya Paternalistik}

Paternalistik, disebut juga oleh Northhouse (1997) sebagai benevolent dictatorship, yaitu mengatur orang dengan cara menindas dengan kebajikan (tanpa kekerasan). Oleh Colella et al. (2005) paternalistik disebut sebagai a hidden and insidious discrimination, yang berarti diskriminasi berbahaya yang terselubung, karena dalam budaya paternalistik cenderung terjadi kategorisasi orang-orang yang dianggap baik dan buruk bagi elite organisasi. Anggapan baik dan buruk inilah yang membuat sebagian orang terdiskriminasi secara sepihak oleh elite organisasi. Budaya ini bersifat relasional, mirip sebagai hubungan antara ayah dengan anaknya yang memiliki sedikit kebebasan.

Budaya paternalistik dapat dibedakan dalam dua jenis, yaitu jenis benevolent dan exploitative (Aycan, 2006). Dalam paternalistik berjenis benevolent, atasan (patron) memiliki kesadaran untuk memperhatikan dan menyejahterakan bawahannya (client). Sehingga, client akan mematuhi dan loyal kepada patronnya dalam relasi yang suka rela. Adapun paternalistik berjenis exploitative, patron memerhatikan client-nya hanya jika client bersedia mengikuti apa yang dikehendaki oleh patron. Client pada akhirnya dapat terlihat patuh dan loyal, namun tidak secara sukarela melainkan terpaksa, dan loyalitasnya sebatas pada sepanjang patron dapat memenuhi kebutuhan client. Sebaliknya, jika client gagal memperlihatkan kepatuhan dan loyalitas, maka patron dapat dengan mudahnya mengeluarkan client dari lingkungan yang melingkupinya. Namun demikian, kedua jenis paternalistik tersebut memiliki kesamaaan, yaitu menginginkan loyalitas dan kepatuhan.

Dalam hal model kepemimpinan, pemimpin di lingkup buda- 
ya paternalistik biasa menerapkan gaya di antara democratic dan authoritarian. Namun demikian, paternalistik lebih mengarah kepada authoritarian (Jackson, 2016). Para atasan dalam menggalang kepatuhan dan loyalitas kolektif, sebagai tujuan dari paternalistik, banyak menggunakan cara authoritarian. Para atasan, cenderung melakukan kontrol ketat dengan pengawasan melekat ataupun aturan legal, tidak banyak memberikan ruang privasi kepada bawahan, termasuk dalam hal berpendapat ataupun berdiskresi. Bawahan melaksanakan perintah atasan karena ingin mendapatkan reward dan menghindari punishment. Budaya paternalistik cenderung menciptakan sebuah lingkungan keluarga dalam organisasi (Jackson, 2016), oleh karena itu seorang patron selalu memosisikan diri sebagai orang tua yang selalu benar sedangkan client-nya dianggap sebagai anak-anak yang selalu harus dibina dan dibimbing.

\section{3.Whistleblowing sebagai Praktik Integritas}

Integritas dalam hal ini adalah sebuah habitus moral (Haryatmoko, 2011), yang pembentukannya tidak sekedar masalah niat baik, tetapi perlu ditopang oleh lingkungan dan pengalaman yang menyediakan infrastruktur etika. Senada dengan pendapat tersebut, Endro (2017) menyatakan bahwa integritas merupakan suatu keutamaan, suatu karakter baik manusia atau budaya baik organisasi, yang menimbulkan daya dorong bagi pemiliknya untuk mewujudkan keputusan dan tindakan bagi kebaikan bersama.

Korupsi, kecurangan atau tindakan tidak benar (wrongdoing) lainnya, sebagai suatu hal yang biasa dianggap berlawanan dengan integritas (Endro, 2016), yang terjadi di internal organisasi sulit dibongkar ketika para pihak yang terlibat bersepakat saling menutupi atau melakukan 'konspirasi' (De Maria, 2006). Menurut De Maria, konspirasi perilaku korupsi di dalam organisasi terjadi karena adanya sinergitas antara sifat kerahasiaan (secret) dan aksi tutup mulut (silence) yang dilakukan para pihak yang terlibat.

Untuk mereduksi adanya konspirasi dan sikap permisif atas perilaku wrongdoing, peran aktif dari setiap anggota organisasi un- 
tuk berani melawan kejahatan menjadi sebuah keniscayaan. Edmund Burke (1729-1797) menyatakan bahwa, "The only thing necessary for the triumph of evil is the good men to do nothing. " (satu-satunya yang diperlukan bagi kemenangan kejahatan adalah orang-orang baik yang berdiam diri). Sikap tidak peduli, masa bodoh dan pasif (hibernation) justru menjadi penghalang besar dalam upaya pencegahan tindakan wrongdoing. Sikap permisif juga dapat menurunkan kepercayaan diri orang-orang yang berintegritas untuk berani mengatakan bahwa tindakan korupsi, sebagai salah satu tindakan wrongdoing, adalah suatu kejahatan dan musuh bersama.

Isu dan kondisi di atas semakin memperkuat argumentasi bahwa orang dalam (insider) yang mengetahui adanya praktik tidak sehat di tempatnya bekerja dan kemudian memutuskan menjadi whistleblower bukanlah sebuah perkara yang mudah. Beberapa studi terdahulu menunjukkan bahwa bahwa kondisi dilematis yang dialami whistleblower merupakan konsekuensi sekaligus risiko yang melekat (inherent) pada setiap tindakan whistleblowing. Bentuk respons organisasional yang unpredictable menempatkan whistleblower pada kondisi yang dilematis (Keenan, 1990; Lindblom, 2007; Teo dan Caspersz, 2011). Kondisi yang dialami whistleblower menjadi semakin dilematis apabila kasus yang diungkap atau dibongkar adalah kasus atau kejahatan yang terorganisasi secara sistemastis serta dilakukan atau melibatkan orang-orang penting atau para petinggi di dalam organisasi tempat whistleblower bekerja.

Vandekerckhove dan Tsahuridu (2010) berargumentasi bahwa tindakan whistleblowing adalah tugas positif dan apabila tidak dilakukan dapat menimbulkan pelanggaran moral. Namun demikian, keduanya mengemukakan bahwa tindakan whistleblowing tidak termasuk dalam kategori tanggung jawab hukum (legal responsibility). Argumentasi ini memosisikan tindakan whistleblowing pada dua perspektif yaitu sebagai hak atau sebagai kewajiban (Tsahuridu dan Vandekerckhove, 2008). Dalam konteks yang lebih luas, Dworkin dan Near (1997) menyatakan bahwa tindakan whistleblowing adalah manifestasi tindakan kewarganegaraan yang baik, seharusnya didu- 
kung dan selayaknya diberikan penghargaan. Dozier dan Miceli (1985) juga bependapat bahwa tindakan whistleblowing merupakan salah satu bentuk perilaku prososial (prosocial behavior) yang menitikberatkan pada upaya membantu pihak lain dan mendorong kemajuan organisasi.

Endro (2017) menyatakan bahwa sosok individu yang berintegritas tidak sekadar menyerahkan diri pada pengaruh luar atau mengubah dirinya menjadi sosok lain tergantung konteks hidupnya, melainkan tetap bertahan dengan perilaku yang menunjukkan satu identitas dirinya yang asli dalam berbagai konteks hidupnya. Dengan demikian, tindakan whistleblowing merupakan salah satu ekspresi identitas. Identitas yang dipilih oleh seseorang yang dinyatakan secara aktif melalui pilihan tindakan yang seharusnya dilakukan karena ada nilai lebih yang akan diperoleh dengan pilihan identitas dan tindakan itu. Di sini, integritas bukan menyatakan fakta apa yang terjadi, melainkan menyatakan apa yang seharusnya diupayakan.

\section{B. PEMBAHASAN}

\section{Konteks Budaya Paternalistik Kota Tegal}

Budaya paternalistik di Pemkot Tegal saat itu terlihat cenderung mengarah pada authoritarian. Beberapa pihak menuturkan dalam wawancara, bahwa Wali Kota Tegal, Siti Mashita Suparno (SMS), menginginkan para birokrat patuh terhadap segala kebijakan yang diinginkannya. Alat pengatur utama saat itu, bukanlah ketentuan formal yang telah ditetapkan sebelumnya, tetapi lebih banyak pada seruan dan perintah langsung wali kota. Wali Kota SMS mendapat dukungan penuh dari seorang pengusaha bernama Amir Mirza Hutagalung (AMH), yang pada akhirnya banyak melakukan intervensi di birokrasi dan memiliki peran lebih besar dari pada wakil wali kota. Wali Kota SMS saat itu mengajarkan kepada semua orang agar memanggil dirinya dengan sebutan 'bunda'. Sebuah upaya agar tercipta relasi patron dengan client-nya sebagaimana sebuah relasi orang tua dengan anak-anaknya (Jackson, 2016). 
Budaya paternalistik di Kota Tegal juga cenderung eksploitatif. Seperti yang dinyatakan oleh Aycan (2006), bahwa atasan (patron) akan memperhatikan client-nya hanya jika client bersedia mengikuti apa yang dikehendaki oleh patron. Dari hasil beberapa wawancara yang penulis lakukan, wali kota SMS terlihat menginginkan kepatuhan kolektif, terlihat dari beberapa usaha yang dilakukannya dengan cara memberikan fasilitas kesejahteraan dan jabatan kepada siapa saja yang loyal kepada dirinya. Hal itu dilakukan sekaligus untuk merotasi jabatan, terutama bagi pejabat yang menolak untuk patuh. Meskipun demikian, kesempatan menjadi pejabat bukanlah tanpa pengorbanan, mereka diharuskan membayar sejumlah uang tertentu untuk mendapatkannya. Beberapa pegawai menyambutnya dengan suka cita. Mereka berpendapat bahwa inilah saatnya mereka dapat menduduki jabatan dengan cepat, tanpa mengikuti tahapan uji kelayakan ataupun prosedur promosi sesuai ketentuan. Mereka merasa mendapatkan penghargaan atas kepatuhannya, meskipun dengan cara menyetorkan sejumlah uang. Client pada akhirnya terlihat patuh dan loyal, tetapi tidak secara suka rela melainkan terpaksa, hanya karena patron terlihat mampu memenuhi kebutuhan client.

Diskriminasi sebagai salah satu konsekuensi budaya paternalistik (Colella et al., 2005), terlihat jelas di Kota Tegal. Dari hasil wawancara yang peneliti lakukan, diskriminasi tampak dari adanya kategorisasi pegawai, baik dan buruk, yang dinyatakan oleh wali kota di berbagai kesempatan. Beberapa nama pegawai yang terbukti patuh dan loyal serta pegawai yang selalu tidak melaksanakan kebijakannya, disebutkan sebagai role model baik dan buruk. Para pegawai diimbau untuk meneladani pegawai yang dianggap baik, sebaliknya bagi pegawai yang masuk dalam kategori pegawai buruk akan terkena hukuman. Pegawai 'buruk' terdiskriminasi melalui mutasi besar-besaran yang menempatkan mereka pada Organisasi Perangkat Daerah (OPD) maupun posisi jabatan yang dianggap tidak strategis, seperti di Dinas Perpustakaaan dan Arsip, serta beberapa kecamatan dan kelurahan.

Beberapa kondisi di atas, dianggap oleh sebagian birokrat se- 
bagai tindakan yang tidak sesuai dengan nilai-nilai budaya setempat dan merusak tatanan birokrasi. Sebagaimana dinyatakan salah seorang tokoh pergerakan perlawanan, bahwa nilai budaya Tegal telah dirusak oleh wali kota, sampai kemudian beredar pesan berantai di media sosial dan pesan elektronik kepada banyak birokrat dengan judul 'rumah saya sudah rusak' (wawancara dengan HGWP, 12 Februari 2018).

Nilai-nilai budaya lokal yang ingin dipertahankan oleh sebagian pegawai yang kemudian melawan tindakan wali kota adalah prinsip (sesanti) Ki Gede Sebayu tentang kepemimpinan. Ki Gede Sebayu adalah tokoh pendiri Tegal yang memiliki prinsip kepemimpinan yaitu "ngayomi, ngayahi, ngayemi" (melindungi, melayani, menyejahterakan, hadir dan peduli). Oleh karena itu, maka arogansi, kesewenangan, tidak taat aturan, dan segala bentuk penyimpangan yang akan menimbukan persoalan di masyarakat jelas tidak sesuai atau bertentangan dengan ajaran Ki Gede Sebayu yang dinilai sebagai kearifan lokal (Soetjiptoni, 2007).

\section{Perlawanan Terhadap Budaya Paternalistik}

Tindakan wali kota yang tidak sesuai dengan nilai-nilai budaya lokal dan merusak tatanan birokrasi itulah yang kemudian menjadi alasan utama perlawanan beberapa birokrat di Kota Tegal. Dengan demikian dapat dikatakan bahwa sekelompok birokrat Kota Tegal, melakukan adaptasi terhadap situasi budaya paternalistik untuk mempertahankan sebuah budaya yang tumbuh di lingkungan eksternal birokrasi. Situasi perlawanan demikian memenuhi syarat sebagai perlawanan budaya, yang disebut oleh Hebdige (2003) sebagai perlawanan konjungtural dan relasional. Namun demikian, perlawanan terhadap budaya paternalistik tersebut tidak disadari oleh para birokrat yang melakukan perlawanan. Para birokrat hanya menyadari bahwa perlawanan yang mereka lakukan adalah melawan tindakan tidak benar yang dilakukan wali kota dan jajarannya.

Dalam berbagai kasus perlawanan budaya, biasanya ditandai juga dengan beberapa pemaknaan ulang terhadap simbol-simbol se- 
buah budaya yang dilawannya (Barker, 2009). Menurut Thompson (2004), proses penerimaan pesan dari simbol bukanlah sebagai proses yang bersifat pasif, melainkan merupakan proses intepretasi dan evaluasi yang reaktif. Pertentangan nilai simbol itu disebut sebagai konflik valuasi simbol.

Budaya paternalistik, termasuk juga di Kota Tegal, memiliki banyak simbol yang dipelihara dan sebagian dijadikan penanda identitas. Istilah sebutan 'bunda', kategorisasi pegawai loyal dan pembangkang, role modelling pegawai baik dan buruk, hingga nada dan bahasa perintah dengan ancaman, adalah serangkaian simbol yang mengukuhkan budaya paternalistik.

Sebutan 'bunda' yang disematkan sendiri oleh wali kota, bagi sebagian pegawai dimaknai sebagai orang tua yang harus dihormati. Namun bagi sebagian pegawai lainnya, sebutan tersebut dimaknai sebagai seseorang yang memiliki ambisi untuk berkuasa secara absolut. Beberapa pegawai yang memberi makna ulang tersebut beralasan bahwa sebutan itu hanya digunakan untuk mengokohkan posisinya dan menarik simpati orang agar mengikuti segala kemauannya. Adapun kemauan 'bunda' tidak sesuai dengan nilai-nilai luhur yang dianut oleh masyarakat Tegal.

Sekelompok pegawai ini justru kemudian memberi gelar berbeda kepada wali kota, yaitu sintren. Sebutan sintren mengacu pada peran seseorang dalam sebuah seni pertunjukan masyarakat Banyumas. Sintren tersebut digambarkan sebagai seorang perempuan yang berubah wujud menjadi seseorang yang cantik dan berdandan menor, tetapi jiwanya terasuki oleh roh lain, atau yang biasa disebut dengan istilah kesurupan (Herususanto, 2008). Sintren, bagi beberapa pegawai yang ingin mempertahankan nilai-nilai budaya Tegal, menjadikan sebutan tersebut sebagai sebutan sehari-hari menggantikan 'bunda'.

Kategorisasi pegawai loyal dan pembangkang yang sering didengungkan oleh wali kota, tidak lagi dimaknai sebagaimana keinginan budaya paternalistik, yaitu loyal-pembangkang dalam arti setia mengikuti/menolak perintah atasan. Bagi sebagian pegawai, loyal justru dimaknai sebagai sifat yang tidak memiliki kepedulian 
terhadap kondisi birokrasi. Lebih dari itu, loyalitas justru disamakan dengan ketidakberanian pegawai untuk melawan kesewang-wenangan.

Istilah loyal versus pembangkang kemudian diubah oleh sebagian pegawai menjadi 'jihaders versus penjilat'. Sebagian pegawai yang berani memperjuangkan nilai-nilai luhurnya dan kemudian bergerak bersama untuk melawan, menamakan dirinya sebagai 'jihaders'. Mereka juga menyebut pegawai yang loyal kepada wali kota sebagai 'penjilat'.

Dengan demikian, dapat dikatakan bahwa upaya perlawanan yang dilakukan oleh sebagian birokrat Pemkot Tegal untuk melawan tindakan wali kota, sebenarnya juga sekaligus merupakan bentuk perlawanan terhadap budaya paternalistik, meskipun hal itu dilakukan di luar kesadaran para birokrat.

\section{Pengungkapan (Whistleblowing) Sebagai Strategi Per- lawanan}

Suatu perlawanan terhadap budaya dapat muncul dari hubungan kekuasaan dominan dan subordinasi, dimana budaya yang mendominasi berusaha memaksakan dirinya kepada pihak subordinat. Dalam hal ini, kekuasaan dominan dijalankan oleh patron (pimpinan) dan subordinat adalah client (para birokrat). De Certeau (1984) menjelaskan sebuah taktik perlawanan budaya, diantaranya melalui penggunaan sumber daya lain untuk berusaha menciptakan ruang yang dapat ditinggali. Sebagian birokrat Kota Tegal yang melawan, memilih perlawanan dengan menggunakan sumber daya berupa organisasi Korps Pegawai Repulik Indonesia (Korpri). Penggunaan sumber daya tersebut menciptakan sebuah ruang yang dapat 'ditinggali' dan digunakan para birokrat untuk mengungkap berbagai tindakan wali kota.

Tindakan pengungkapan tersebut menjadi sebuah strategi perlawanan, bukannya tanpa alasan. Perlawanan dengan cara membangkang untuk sekadar tidak melaksanakan kebijakan pimpinan, atau melakukan mogok kerja, dinilai tidak akan menyelesaikan permasalahan, tetapi justru berakibat buruk pada diri individu, birokrasi, 
maupun masyarakat luas sebagai pihak yang harus dilayani.

Brenkert (2010) mengatakan bahwa strategi melaporkan dan mengungkap kondisi yang terjadi kepada publik atau pihak-pihak yang dipandang memiliki kapasitas, dapat menghentikan atau mencegah terjadinya praktik tidak sehat yang terjadi, baik secara langsung maupun tidak langsung di sebuah organisasi. Tindakan perlawanan yang dimanifestasikan dalam bentuk pengungkapan tersebut secara teknis maupun substansi, pada hakikatnya memiliki makna yang sejalan dengan tindakan yang dikenal dengan istilah whistleblowing. Istilah whistleblowing oleh Miceli dan Near (1984) didefinisikan dengan narasi sebagai berikut:

Whistleblowing didefinisikan sebagai pengungkapan oleh anggota organisasi (mantan ataupun saat ini) atas tindakan ilegal atau praktik yang tidak semestinya yang dilakukan oleh seseorang, kepada person atau organisasi yang mampu memengaruhi tindakan. Miceli dan Near (1984: 689).

Lebih lanjut, para birokrat Kota Tegal tersebut juga menganggap bahwa perlawanan tidak dapat dilakukan oleh perorangan ataupun sekumpulan kecil birokrat saja, karena melawan 'raksasa' harus dilakukan dengan cara bersama-sama. Dalam berbagai wawancara dengan beberapa tokoh pergerakan (KH dan AK, 10 Maret 2018), mereka mengatakan bahwa, kunci perlawanan dalam menegakkan integritas adalah solidaritas, tanpa itu birokrat tidak dapat berbuat banyak. Bahkan mereka meyakini bahwa, jika seluruh birokrat Kota Tegal saat itu bersatu, proses perlawanan tidak akan berlarut-larut dan mungkin KPK pun tidak perlu turun tangan melakukan OTT.

Gerakan moral birokrat ini diawali dengan adanya pertemuan para tokoh birokrat yang difasilitasi oleh lembaga Korpri Kota Tegal. Forum tersebut membahas berbagai fakta atau kondisi birokrasi yang berkembang pada saat itu. Terdapat tujuh rumusan kondisi, yang dituangkan dalam sebuah Surat Pernyataan Sikap Moral Aparatur Sipil Negara Pemerintah Kota Tegal (Superkap), tertanggal 8 April 2015. 
Tujuh rumusan kondisi tersebut adalah, pertama, terjadi disharmonisasi antara Wali Kota dan Wakil Wali Kota Tegal yang berakibat pada tidak berjalannya penyelenggaraan tata kelola pemerintahan dengan baik. Kedua, adanya arogansi dan kesewenang-wenangan kepemimpinan Wali Kota Tegal terhadap aparat birokrasi di lingkungan Pemkot Tegal. Ketiga, adanya campur tangan atau intervensi yang dilakukan pihak yang secara legal formal tidak memiliki kewenangan dalam penyelenggaraan pemerintahan, yaitu AMH. Keempat, adanya tekanan (pressure) terhadap para pejabat maupun staf di lingkungan Pemkot Tegal yang dilakukan, baik oleh Wali Kota SMS maupun oleh AMH yang bertindak seolah-olah sebagai wali kota dan tindakannya telah melampaui batas kewenangan wali kota. Kelima, pemanfaatan birokrasi untuk memberikan pelayanan prima kepada individu wali kota bukan kepada masyarakat. Keenam, pelaksana tugas sekretaris daerah (sekda) telah mengabaikan tugastugasnya dan tidak memberikan pembelaan terhadap permasalahan yang dialami PNS di lingkungan Pemkot Tegal. Ketujuh, Wali Kota Tegal telah melanggar sumpah jabatan dengan lebih mengutamakan kepentingan pribadi dan kelompok dari pada kepentingan masyarakat Kota Tegal.

Serangkaian pengungkapan kemudian dilakukan untuk mengungkap berbagai tindakan tidak benar wali kota. Pertama kali yang dilakukan adalah audiensi dengan para wakil rakyat (DPRD Kota Tegal) pada tanggal 9 April 2015. Dalam forum tersebut, Korpri Kota Tegal menyampaikan Superkap. Melalui Superkap, Korpri Kota Tegal mengajukan dua poin tuntutan yaitu, pertama, mendesak DPRD Kota Tegal melakukan evaluasi secara terbuka atas kepemimpinan Wali Kota SMS; dan kedua, menolak kepemimpinan SMS sebagai wali kota dengan ancaman melakukan mogok kerja, jika SMS tetap dipaksakan menjadi Wali Kota Tegal. Namun demikian, pihak DPRD tidak memberikan respons atau arahan yang tegas atas pernyataan sikap dan tuntutan yang diajukan oleh para birokrat Kota Tegal.

Kondisi tersebut tidak memadamkan semangat perjuangan. Langkah selanjutnya, perwakilan Korpri Kota Tegal melaporkan 
situasi birokrasi Kota Tegal kepada Gubernur Jawa Tengah, Ganjar Pranowo. Menurut tokoh pergerakan, yaitu AK dan HGWP (wawancara 13 Februari 2018), gubernur hanya menitipkan pesan kepada para birokrat bahwa, jika berani (melawan) jangan takut, begitu juga sebaliknya, jika takut jangan berani.

Respons gubernur tersebut disikapi Korpri Kota Tegal sebagai tantangan untuk melanjutkan gerakan perlawanan secara lebih terbuka. Para jihaders, demikian para birokrat melawan menamakan dirinya, memutuskan menggelar demonstrasi (demo) untuk mengungkap ke publik sekaligus memperlihatkan kepada sesama birokrat Kota Tegal bahwa ada permasalahan yang sedang terjadi di kantor wali kota. Demo berlangsung selama kurang lebih dua bulan dan berhasil mendapat banyak dukungan dari kalangan birokrat Kota Tegal serta berbagai elemen masyarakat. Demo digelar dengan harapan agar Wali Kota SMS mau memperbaiki sikap dan menciptakan situasi birokrasi menjadi lebih kondusif. Selain demo, kampanye-kampanye tentang pergerakan dan perlawanan juga dilakukan di berbagai media sosial. Kampanye tersebut bertujuan untuk menyadarkan sesama birokrat agar ikut bersama-sama berjuang melawan arogansi kepemimpinan SMS.

Dampak adanya perlawanan yang dilakukan para birokrat Kota Tegal, Wali Kota SMS melakukan perlawanan balik (retaliation) berupa pencopotan jabatan terhadap 14 pejabat (non-job), penurunan pangkat terhadap dua orang pejabat dan pemindahtugasan (mutasi) beberapa staf pemkot yang terlibat aktif dalam gerakan perlawanan yang dicap oleh wali kota SMS sebagai "pembangkang". Pada tanggal 21 April 2015, wali kota menerbitkan Surat Keputusan (SK) Non Job terhadap 14 orang pejabat Pemkot Tegal.

Genderang perang semakin keras ditabuh. Menyikapi proses non-job yang tidak prosedural tersebut, maka 9 orang yang telah di non-job (non-jober), lima orang di antaranya mengundurkan diri dari proses gugatan, melakukan gugatan di Pengadilan Tata Usaha Negara (PTUN). Gugatan ini dimenangkan oleh para non-jober. Para non-jober sebenarnya hanya berharap agar wali kota SMS ber- 
besar hati untuk mengembalikan kembali jabatan mereka pada posisi semula karena putusan PTUN sudah berkekuatan hukum tetap (inkracht van gewisden). Namun demikian, SMS tetap bergeming dan tidak bersedia melaksanakan putusan pengadilan tersebut.

Perjuangan para jihader, yang beberapa di antaranya adalah juga non-jober, tidak berhenti sampai titik ini. Upaya pelaporan atas kasus ini juga dilakukan kepada berbagai pihak yang dipandang memiliki kekuatan dan kewenangan untuk menyelesaikan permasalahan birokrasi Kota Tegal. Korpri Kota Tegal melaporkan kasus ini kepada Mabes Polri, Korpri Provinsi Jawa Tengah, Korpri Pusat dan beberapa kementerian/lembaga pemangku kepentingan (di antaranya Kemendagri, Kemen PAN dan RB dan Komisi Aparatur Sipil Negara) yang dinilai dapat memberikan dukungan dan dapat memperbaiki situasi yang terjadi.

Setelah berbagai upaya dilakukan, sampai pada akhirnya perjuangan para ASN Pemkot Tegal menemukan jalan lain. Berbekal berbagai bukti kecurangan yang diperoleh dari berbagai pihak, Korpri melaporkan dugaan kasus suap dan berbagai praktik jual-beli jabatan yang dilakukan SMS dan AMH kepada Komisi Pemberantasan Korupsi (KPK). Puncaknya, Wali Kota SMS tumbang akibat persekongkolan tindak kecurangan yang dilakukan bersama AMH. Sebelum masa jabatan SMS berakhir, SMS diciduk melalui Operasi Tangkap Tangan (OTT) KPK pada hari Selasa, 29 Agustus 2017.

Para birokrat Kota Tegal secara kolektif memilih untuk mengungkap dan melaporkan berbagai tindakan menyimpang yang terjadi dengan harapan fakta yang terjadi di internal birokrasi menjadi 'informasi publik' yang diketahui baik oleh segenap internal birokrasi maupun pihak eksternal, dalam hal ini publik dan institusi yang berwenang. Strategi perlawanan ini dilakukan untuk mendapat dukungan, baik secara moril maupun dukungan dalam bentuk upaya perbaikan atas kondisi yang terjadi. Situasi paternalistik tumbuh subur dalam lingkungan kolektif (Jackson, 2016), untuk itu strategi perlawanan yang tepat adalah melakukannya dengan cara kolektif pula. 
Dapat dikatakan, tindakan whistleblowing tersebut dilakukan secara kolektif dan terorganisasi melalui gerakan moral dalam wadah Korpri Kota Tegal. Model pengungkapan (whistleblowing) seperti ini, -sebagai bentuk perlawanan dalam mempertahankan integritas birokrasi di tengah suasana budaya paternalistik yang dilakukan birokrat Kota Tegal- tergolong unik dan berbeda dengan kebanyakan kasus whistleblowing. Pada umumnya tindakan whistleblowing lebih bersifat sporadis dan dilakukan secara individual oleh orang yang berasal dari internal organisasi (insider) (kasus whistleblowing yang diteliti oleh Awaludin, 2011, 2016 dan Nurhidayat, 2017).

Perjuangan yang dilakukan oleh sekelompok birokrat di Kota Tegal ini bukan bertujuan untuk mencari kemenangan dalam arti menggulingkan posisi wali kota, melainkan untuk mempertahankan nilai-nilai luhur budaya Tegal yang telah terusik oleh tindakan kesewenangan wali kota yang memanfaatkan budaya paternalistik di birokrasi. Salah satu tokoh pergerakan menuturkan dalam sebuah wawancara bahwa, para birokrat yang melakukkan perlawanan tidak memedulikan perjuangan yang dilakukan akan berhasil atau tidak, tapi mereka hanya ingin mengingatkan kepada wali kota dan jajarannya yang loyal agar sadar dan bersedia mengubah sikap dan kembali pada tatanan birokrasi (KH, wawancara 10 Maret 2018).

Hal ini sesuai dengan penjelasan Barker (2009) bahwa perlawanan terhadap suatu budaya bukan masalah berhasil atau tidaknya perlawanan, tapi tentang bagaimana sekelompok orang melawan dan memperjuangkan nilai-nilai yang diyakininya, yang berbeda dengan budaya dominan yang melingkupinya.

\section{PENUTUP}

\section{Simpulan}

Perlawanan secara terbuka yang dilakukan oleh birokrat terhadap elite birokrasi belum pernah ditemukan sebelumnya di Indonesia, baik di pemerintahan tingkat pusat maupun tingkat daerah. Perlawanan yang dilakukan oleh sekelompok birokrat di Pemerintah 
Kota Tegal, pada dasarnya sekaligus sebagai bentuk perlawanan terhadap budaya paternalistik, meskipun hal itu tidak disadari oleh para birokrat.

Budaya paternalistik yang menyelimuti birokrasi menginginkan kepatuhan kolektif, maka perlawanan yang dilakukan pada budaya tersebut hanya dapat efektif jika dilakukan dengan cara kolektif pula. Kolektivitas inilah yang membangkitkan solidaritas dan soliditas di antara para birokrat. Kolektivitas ini pula yang membuat para birokrat memiliki keberanian untuk melawan. Tindakan mengungkap dengan cara kolektif terbukti efektif bukan hanya untuk menggalang kekuatan, tetapi juga untuk menyadarkan birokrat lainnya bahwa solidaritas birokrat memiliki kekuatan untuk melawan elite yang melakukan tindakan wrongdoing.

Pengungkapan (whistleblowing) terpilih menjadi strategi yang digunakan dalam dalam melawan. Hal itu dilakukan untuk menghindari tindakan 'konyol' perlawanan, sekaligus agar tugas sebagai birokrat dalam melayani masyarakat tetap dapat berjalan. Perlawanan di tengah budaya paternalistik tidak dapat dilakukan dengan 'serangan' frontal kepada pihak patron, karena itu hanya akan menimbulkan kekalahan di awal perlawanan. Demikian juga perlawanan dengan cara diam (mogok kerja) hanya akan merugikan masyarakat sebagai pengguna layanan birokrasi.

Informasi diungkapkan tidak hanya kepada lingkup internal, dalam hal ini sesama birokrat, tetapi juga kepada pihak eksternal birokrasi, yaitu masyarakat luas. Dengan demikian kekuatan modalitas sosial internal terdukung oleh kekuatan modalitas sosial secara eksternal. Dukungan eksternal tersebut diperlukan justru untuk menjaga kolektivitas internal agar semakin kuat.

Perlawanan juga terbukti efektif dengan memanfaatkan organisasi pegawai, yaitu Korpri. Dengan menggunakan organisasi yang sah, perlawanan memiliki kekuatan terlegitimasi dalam mengatasi berbagai tudingan pembangkangan terhadap birokrasi.

Setelah tertangkapnya Wali Kota SMS oleh KPK, pergerakan tidak kemudian berakhir dan membubarkan diri. Sampai dengan saat 
dilakukannya penelitian, secara informal, wadah pergerakan tetap ada dan solid. Personel yang tergabung dalam pergerakan perlawanan, masih berada di berbagai grup di media sosial. Wadah informal tersebut masih seringkali digunakan sebagai media pengawasan informal dengan mendiskusikan beberapa tindakan yang berpotensi mengarah pada wrongdoing yang dilakukan oleh elite maupun birokrat di Pemkot Tegal.

Namun demikian, kajian ini belum banyak mendapatkan data mengenai relasi patron-client dalam kehidupan birokrasi di Kota Tegal, di saat rezim Wali Kota SMS berganti. Data tersebut penting diperoleh pada penelitian berikutnya agar dapat membandingkan relasi patron-client antar rezim kepemimpinan untuk menilai lebih jauh potensi kekuatan birokrat dalam mempertahankan integritasnya, pascapergerakan perlawanan di masa rezim wali kota SMS.

\section{Saran}

Terhadap berbagai fenomena yang penulis temui dalam proses penelitian, tentunya terdapat beberapa hal yang dapat dijadikan sebagai pembelajaran (transformative learning) untuk dapat diterapkan dan dikembangkan di institusi pemerintahan lainnya. Beberapa hal tersebut di antaranya mengenai keberdayaan birokrat dalam berintegritas serta lembaga Korpri yang sebaiknya mengubah citra dan jati dirinya.

Untuk itu, penulis menyarankan sekaligus menyerukan kepada para birokrat di seluruh negeri agar lebih percaya diri dengan kemampuan kolektifnya dalam mempertahankan integritas di tengah budaya paternalistik yang menyelimuti birokrasi. Peristiwa perlawanan birokrat di Kota Tegal telah membuktikan bahwa birokrat bukan lagi pihak yang selalu merasa inferior, melainkan justru sebaliknya, memiliki kekuatan besar untuk mengimbangi dominasi elite birokrasi yang saat ini masih lebih banyak diisi oleh para politisi.

Terhadap kekuatan tersebut, penulis menyarankan agar lembaga Korpri mampu memberikan ruang yang cukup bagi para birokrat untuk lebih berdaya. Korpri hendaknya mengubah dirinya menjadi 
kekuatan baru di birokrasi, yaitu sebagai pembina sekaligus pelindung birokrat di wilayah masing-masing. Pengurus Korpri sebaiknya diisi oleh tokoh-tokoh panutan di birokrasi yang telah teruji dedikasi dan integritasnya.

Dengan demikian, Korpri di manapun berada mampu menjadi tempat berkeluh-kesah, berlindung, dan menggalang kekuatan bagi para birokrat dari tindakan kesewenang-wenangan maupun tindakan menyimpang pimpinan atau elite birokrasi. Korpri hendaknya tidak lagi sebagai lembaga normatif yang dibentuk untuk ikut 'menjinakkan' para birokrat, melainkan menjadi lembaga kritis yang mampu menggerakan birokratnya menjadi penyeimbang elite birokrasi

\section{REFERENSI}

Aycan Z (2006). Paternalism: Towards Conceptual Refinement and Operationalization. In: Yang KS, Hwang KK and Kim U (Eds), Scientific Advances in Indigenous Psychologies: Empirical, Philosophical and Cultural Contributions. Cambridge: Cambridge University Press (pp. 445-466).

Awaludin, Arif. (2011). Rekonstruksi Perlindungan Hukum Terhadap Penyingkap Korupsi. Disertasi (tidak dipublikasikan), Program Doktor Ilmu Hukum UNDIP, Semarang . (2016). Ideologi Etis Penyingkap Korupsi Birokra-

si. Pandecta, Vol 11, Nomor 2, Desember: (pp.189-201).

Barker, Chris. (2009). Cultural Studies: Teori dan praktik, Penerjemah: Tim Kunci Cultural Studies Centre, Yogyakarta: PT. Bentang Pustaka.

Brenkert, G. G., (2010). Whistle Blowing, Moral Integrity, and Organizational Ethics. In: G. G. Brenkert, (Eds), The Oxford Handbook of Business Ethics. New York: Oxford University Press, (pp. 563).

Brennan, Niamh \& Kelly, John. (2007). A Study of Whistleblowing Among Trainee Auditors, British Accounting Review, 39 (1) (pp. 61-87) 
Colella A, Garcia F, Reidel L, et al. (2005). Paternalism: "Hidden" Discrimination. Paper tersebut dipresentasikan pada Meeting of the Academy of Management, Honolulu, Hawai

De Maria, William. (2006). Brother Secret, Sister Silence: Sibling Conspiracies against Managerial Integrity. Journal of Business Ethics (2006) 65 (pp. 219-234)

DeZoort, F. T., dan A. T. Lord. (2001). The Impact of Commitment and Moral Reasoning on Auditors' Responses to Social Influence Pressure. Journal of Accounting, Organizations and Society 26 (3): (pp.215-235).

Dozier, Janelle Brinker \& Miceli, Marcia P. (1985). Potential Predictors of Whistle-Blowing: A Prosocial Behavior Perspective. The Academy of Management Review, Vol. 10, No. 4 (pp. 823836)

Dwiyanto, Agus, dkk. (2012), Reformasi Birokrasi Publik di Indonesia, Yogyakarta: Gadjah Mada University Press.

Dworkin, Terry Morehead \& Melissa S. Baucus. (1998). Internal vs. External Whistleblowers: A Comparison of Whistleblowering Processes. Journal of Business Ethics. Vol.17 (pp.1281-1298).

Endro, Gunardi (2017). Menyelisik Makna Integritas dan Pertentangannya dengan Korupsi. Jurnal Antikorupsi Integritas, Vol 03 Tahun 2017 (pp.131-151).

Hall, Stuart (1996). For Allon White: Metaphors of Transgformation dalam D. Morley dan D- K. Chen. London: Routledge.

Hebdige, Dick (2003). Resistance Through Rituals: Youth Subculture in Post War Britain, edited by Stuart Hal \& Tony Jefferson, Taylor \& Francis.

Hofstede G (1980), Cultures Consequences. Thousand Oaks: Sage Hofstede Insight (2017). Hofstede Insight dikutip dari https://www. hofstede-insights.com/country-comparison/indonesia/, diakses pada tanggal 11 Februari 2018.

Jackson, Terence (2016). Paternalistic Leadership: The Missing Link in Cross-Cultural Leadership Studies? International Journal of Cross Cultural Management, Vol. 16 (1) (pp.3-7). 
Johnson, Roberta Ann dan Kraft, Michael F. (1990). Bureaucratic Whistleblowing and Policy Change. The Western Political Quartely Vol.43 No. 4 (Dec) (pp. 849-874)

Keenan, John P. (1990). Upper-Level Managers and Whistleblowing: Determinants of Perceptions of Company Encouragement and Information about Where to Blow The Whistle. Journal of Business and Psychology, Vol. 5, No. 2 (pp.223-235)

Kumorotomo, Wahyudi. (2001). Etika Administrasi Negara: Jakarta: PT Raja Grafindo Persada.

Lindblom, Lars. (2007). Dissolving The Moral Dilemma of Whistleblowing. Journal of Business Ethics. 76 (pp.413-426)

Miceli, Marcia Parmerlee dan Janet P. Near. (1984). "The Relationship among Beliefs, Organizational Position, and WhistleBlowing Status: A Discriminant Analysis" dalam The Academy of Management Journal, Vol. 27(Dec), No. 4 (pp. 687-705).

Miceli, Marcia Parmerlee, Janet P. Near \& Charles R. Schwenk. (1991). Who Blows the Whistle and Why? Industrial and Labor Relations Review, Vol. 45, No. 1 (pp.113-130)

Neuman, W Lawrence. (2013). Metodologi Penelitian Sosial: Pendekatan Kualitatif dan Kuantitatif, Edisi ke tujuh. Jakarta; Indeks

Northouse PG (1997), Leadership: Theory and Practice. Thousand Oaks: Sage.

Nugroho, Fajar Eko (2017, 30 Agustus). PNS Senang Wali Kota Tegal Terjaring OTT KPK. Diperoleh 20 Oktober 2017, dari http://news.liputan6.com/read/3076492/pns-senang-wali-kota-tegal-terjaring-ott-kpk

Nurhidayat, Ilham. (2017). Tindakan Whistleblowing: Dilematika dan Tantangan Etika dalam Organisasi. Disertasi (tidak dipublikasikan), Program Doktor Ilmu Administrasi Publik UGM, Yogyakarta

Price Waterhouse Coopers. (2011). Global Economic Crime Survey 2011 (40 page PDF document), dikutip pada tanggal 2 December 2011 dari http://www.pwc.com/en_GX/gx/economic- 
crimesurvey/assets/GECS_GLOBAL_REPORT.pdf

Setianto, Vania Yunita, Utami, Intiyas, \& Novianti, Suzy. (2016).

Whistleblowing Dalam Tekanan Ketaatan dan Kepercayaan pada Pimpinan, Jurnal Ekonomi dan Bisnis, Volume XIX No. 3 (pp.485-510).

Soetjiptoni, (2007). Ki Gede Sebayu, Pendiri Pemerintahan Tegal, Tahun 1585-1625, Citra Bahari Animasi, Tegal.

Storey, John. (2008). Cultural Studies dan Kajian Budaya Pop, Penerjemah: Laily Rahmawati, Yogyakarta \& Bandung: Jalasutra.

Tavakoli, A., J.P. Keenan \& B. Crnjak-Karanovic. (2003). Culture and Whistleblowing an Empirical Study of Croatian and United States Managers Utilizing Hofstede's Cultural Dimensions, Journal of Business Ethics, 43:1/2, (pp.49)

Teo, H. \& Caspersz, D. (2011) Dissenting Discourse: Exploring Alternatives to The Whistleblowing Silence Dichotomy. Journal of Business Ethics, 104, 2 (pp.237-49).

Thompson, John B. (2004). Kritik Ideologi Global, Penerjemah: Haqqul Yaqin, Yogyakarta: IRCiSoD.

Tsahuridu, Eva E \& Vandekerckhove, Wim. (2008). Organisational Whistleblowing Policies: Making Employees Responsible or Liable? Journal of Business Ethics, Vol. 82, No. 1 (pp.107118).

Vandekerckhove, Wim \& Tsahuridu, Eva E. (2010). Risky Rescues and the Duty to Blow the Whistle. Journal of Business Ethics 97 (pp.365-380). 
198 | INTEGRITAS Volume 4 Nomor 1 - Juni 2018 